\title{
KÍNA HAGYOMÁNYOS STRATÉGIAI KULTÚRÁJA NÉHÁNY KLASSZIKUS IRODALMI PÉLDA TÜKRÉBEN
}

\section{CHINA'S STRATEGIC CULTURE THROUGH SOME LITERARY CLASSICS}

\author{
Rácz Lajos \\ nyugalmazott egyetemi docens, Zrínyi Miklós Nemzetvédelmi Egyetem \\ racz.lajos@hdsnet.hu
}

\begin{abstract}
ÖSSZEFOGLALÁS
Kína ma a nemzetközi élet egyik legfontosabb szereplője, a globális porondon való viselkedését folyamatosan figyelemmel kell követni. A kínai viselkedés megértéséhez közelebb vihet minket a kínai stratégiai hagyomány megismerése, hiszen a kínai döntéshozók ebből a hagyományból is merítenek. Kínában már az ókorban kialakultak a stratégiai gondolkodás különféle iskolái, s a modern nyugati stratégiai tudás fogalmai és koncepciói közül jó néhányat a régi Kínában is megtalálunk. A jelen tanulmány egy híres kínai mesén és néhány ókori szerzőn keresztül szeretné illusztrálni, hogy mit jelent a hagyomány a kínai stratégiában.
\end{abstract}

\section{ABSTRACT}

China is one of the most important actors in international life, and its behaviour on the international stage is worth of continuous observation. The knowledge of Chinese strategical tradition can help us understand the acts of present China, as Chinese decision-makers draw heavily on that tradition. Numerous schools of strategic thinking have emerged in ancient China, and some terms and concepts of modern Western strategical knowledge can already be found in old Chinese texts. The present paper aims to illustrate the role of tradition in Chinese strategy through a well-known Chinese tale and some ancient authors.

Kulcsszavak: Kína, stratégia, Szun-ce, Modi, A hadviselés törvényei

Keywords: China, strategy, Sunzi, Modi, Art of War

Egy régi kínai történetben Tung-kuo (Dongguo) tanár úr elbújtat egy farkast, akit katonák keresnek, és félrevezeti az üldözőket, ezzel megmentvén a toportyánféreg életét. A veszély elmúltával a hálátlan farkas meg akarja enni Tung-kuo tanár urat. Ebből egy erkölcsi és jogi szempontokat felvonultató éles vita kerekedik a gonosz farkas és a jószívü könyvmoly között, amelyben Tung-kuo tanár úr vesz- 
tésre áll. Szerencsére arra jár egy öreg paraszt, aki igazságot tesz: visszacsalogatja a farkast a zsákba, és egy bottal agyonveri.

A történetet minden kínai ember ismeri, már kisgyerekkorukban találkoztak vele diafilmeken, rajzfilmes megvalósításokban (a YouTube-on több klasszikus és modern változat is fellelhető), képregényekben és általános iskolai nyelvtan-, illetve irodalomkönyvekben. Az Eurázsia-szerte népszerü tanmese legrangosabb irodalmi feldolgozása egy Ming-kori (1368-1644) szerző, Ma Csung-hszi (Ma Zhongxi) alkotása, de az ,alapsztori” visszavezethető akár a Han-dinasztiáig (i. e. 206-i. sz. 220), sőt még korábbig. Maga a Középső-hegység, amelynek térségében az események zajlanak, az egykori Csao (Zhao) királyság területén fekszik, amely egyike volt az i. e. 5. században egymás ellen hadakozó hét államnak. A történet alapján később készült egy négyfelvonásos pekingi opera és egy egyfelvonásos színdarab is.

Tien Jüan Tan (Tian Yuan Tan) (2007) rámutat, hogy a mese rejtett mondanivalója megértésének kulcsa az a kérdés, hogy kicsoda a „hálátlan farkas”, és hogyan kell az igaz kínai embereknek felvenni a harcot a hozzá hasonló erkölcstelen, veszélyes figurákkal. A leggyakoribb értelmezések szerint a mese a Ming-kori belpolitikai küzdelmek allegorikus megfogalmazása, amelyben a hálátlan, tehát velejéig gonosz farkas azokat a helytelen gondolkodású konfuciánus hivatalnokokat képviseli, akik nem nyílt vitában (publikációikkal), hanem udvari cselszövések, ármánykodások révén akarnak leszámolni a fölöttük álló szellemi színvonalú ellenfeleikkel, nem riadva vissza a „karaktergyilkosságoktól” vagy akár a fizikai erőszaktól sem. Egyes kutatók konkrétan meg is nevezik azt a két konfuciánus irodalmárt, akiknek vetélkedése ihletet adott Ma Csung-hszinek. Eszerint Kang Haj (Kang Hai) egy Liu Csin (Liu Jin) nevủ eunuch segítségével megmentette kollégáját, Li Meng-jangot (Li Mengyang) a börtöntől, ő azonban éppen Kang és Liu kapcsolatát használta fel arra, hogy megvádolja, és ezzel bajba sodorja jótevőjét, akit emiatt elkergettek a császári udvartól. Az eset politikai hátteréhez éppúgy hozzátartozik az eunuchok és a konfuciánusok közötti hatalmi vetélkedés, mint az írástudók körein belüli frakcióharcok. Ezzel tulajdonképpen eljutottunk a ma is létező „Kína-szindróma” lényegéhez.

A „Kína-szindróma” egy közszájon forgó, allegorikus megfogalmazása annak az összetett problematikának, ami többféleképpen értelmezhető. Teller Ede (1987) Kína-szindrómának nevezte el az önhittséggel vegyes, felfedezésellenes bezárkózási hajlamot, ami a Ming-dinasztia bukásához vezetett, és amitől óva intette az Egyesült Államokat is.

A mesében Tung-kuo tanár úr az „írástudó” konfuciánusokat, a hálátlan farkas talán az álnoknak tartott eunuchokat, azaz a „másként gondolkodó”, a hagyományokat tisztelő kínaiak számára ,idegen” eszméket követő, veszélyes kisebbséget jelképezi. Lázadók, eunuchok, titkos társaságok tagjai tartozhatnak ebbe a körbe. Az öreg paraszt viszont alighanem a társadalom gerincét adó földmüvesek termé- 
szetes pragmatizmusát, vagyis a taoizmus filozófiai irányzatát (az „út és erény” iskoláját) képviseli, ami értékesebb (ez esetben eredményesebb) még a konfuciánus elit elméletieskedő moralizmusánál is.

Vannak azonban a mesének olyan fontos szereplői is, akiknek az elemzők mind ez ideig túlontúl kevés figyelmet szenteltek. A fő kérdés számomra ezért a következő: Kik azok a katonák? Miért üldözik a farkast, és Tung-kuo tanár úr miért vezeti félre őket? Miért hazudja azt, hogy a farkas ,,arra menekült” (amerre a valóságban nem, hiszen az ő könyves batyujában lapított). A cselekmény drámai csúcspontja (szerintem) az a jelenet, amikor a katonai különítmény parancsnoka lováról le se szállva közelebb léptet az olvasást színlelő Tung-kuo mesterhez, és megkérdezi, hogy mi van a zsákjában. A mester pedig azt feleli, hogy könyvek, vagyis lényegében hazudik, mert azt elhallgatja, hogy a farkas is ott gubbaszt a könyvek között. Ha most a katonák átkutatnák a zsákot, akkor Tung-kuo mester lebukna, és alighanem ő is ugyanarra a sorsra jutna, mint a farkas: megölnék. Ne feledjük: a hadakozó fejedelemségek korában vagyunk, vagyis háborús időket élünk. Mi több: az eredeti verzióban maga Csien-ce (Jianzi) herceg, Csao uralkodója vezeti a vadászokat. Tehát a mester a hazugsággal egyenesen felségsértést követett el. A katonák azonban nem ellenőrzik Tung-kuo tanár úr állítását, hanem hisznek neki, és elvágtatnak a jelzett irányba. Tung-kuo mester tehát csak magát okolhatja, hogy ezek után bajba kerül, és hálát adhat jó szerencséjének, hogy az öreg paraszt megmenti.

Az emberek alapvető jóságát feltételező Konfuciusz és a vele szemben álló irányzatok (mindenekelőtt a „legizmus”) ellentéte a mai Kína arculatának kettőségét is meghatározza. A kül- és biztonságpolitikai kapcsolatok terén ez úgy jelentkezik, hogy miközben Peking előszeretettel tünteti fel magát a zsákmányra éhes, agresszív Nyugat jóhiszemú áldozatának, a tipikus amerikai és európai értékelésekben éppen Kína az, aki gátlástalanul tör regionális dominanciára, sőt világuralomra.

Steve Tsang és Honghua Men (2016) szerint az 1949-ben győztes kínai (kommunista) forradalom visszaszerezte a kulturális autonómiát, de szakított a modernizációval. A nagy proletár kulturális forradalom ideológiai nyomása extrém módon homogenizálta a kínai társadalmat, megfosztva azt sokszínüségétől. A társadalom és a kultúra közötti ellentmondások marginalizálták a hagyományokat, sőt azok teljes dezintegrációjával fenyegettek.

Még a Teng Hsziao-ping- (Deng Xiaoping) féle „,reform és nyitás” politika évtizedei sem tudták eloszlatni a Nyugattal szembeni ambivalenciát. A Nyugat-ellenes kínai nacionalisták ma is úgy vélik (részben talán helyesen), hogy a „fogyasztói társadalom" térhódítása átalakítja Kína ethoszát, és elszakítja a társadalmat a saját kulturális szellemiségétől. Mindez az „elit” gondolkodására is kihat, és egyes értelmiségi köröket elutasító hozzáállásra ösztönöz a hagyománytisztelettel szemben. Ez a mai Kína modernizációs csapdája. 
A történelmi tapasztalatok szerint, ha a modernizáció megpróbál rákényszeríteni az emberekre egy kulturális és nemzeti azonosságot, akkor ellenállást szül, bel- és külföldön egyaránt. Ez pedig a mai Kína „soft power csapdája”. Ha a „soft power" a nemzetközi politikai játszmák eszközévé válik, akkor elveszíti hatékonyságát és vonzerejét. A „kulturális ipart” csak fokozatosan, a tolerancia és a pluralizmus jegyében volna célszerủ fejleszteni. Túl kellene lépni a piacorientált megközelítésen. A kulturális termékek világpiacán Kína részesedése rohamosan növekszik, de nincs jele annak, hogy a kínai civilizáció alapértékei mélyebb ismertségre és elfogadottságra tennének szert.

A ,puha erők" összemérésének harcmezeje az internet. Az ideológiaexport a nyilvános diplomácia eszköze. A blogoszférát fokozatosan felváltja a Facebook-, azt pedig a Twitter-korszak. A kínai filozófia önkifejezési módját a rövid szövegek, a „beszélgetések és mondások” jellemzik, a Twitter-üzenetek mégsem $H s z i$ Csin-ping (Xi Jinping), hanem Donald Trump kezében váltak veszélyes - igaz, kétélü - fegyverré.

A nemzetközi színtéren, napjaink hiperkompetitív viszonyai között az össznemzeti erő „kemény” összetevői közül a katonai, a gazdasági és a technológiai képességek kerülnek előtérbe, és főszerep jut mindezek átfogó fejlesztésének, amit a „nemzeti” kulturális, sőt civilizációs értékeket megőrizve továbbfejlesztő „nagy stratégia” foglal egységbe.

A modernizációs-globalizációs hullámok részeként, a stratégia tudományának területén a második világháború után vette kezdetét egy korszakalkotó, forradalmi átalakulás. A hidegháborút jellemző stratégiai fogalmakat Thomas Schelling dobta be a tudományos köztudatba 1960-as, A konfliktusok stratégiája címü könyvében (Schelling, 1980). Ez irányú kutatásaiért 2005-ben közgazdasági Nobel-dijat kapott ,,a konfliktusok és az együttmüködés játékelméleti elemzés révén történő jobb megértéséhez" való hozzájárulásának köszönhetően. Schellingnek külön érdeme, hogy az igencsak mélyen szántó gondolatait a társadalomtudósok által is nehezen érthető, bonyolult matematikai formulák helyett természetes emberi nyelven, szövegesen tudta rendkívül világosan megfogalmazni. Talán ez az oka annak, hogy - a klasszikus kínai műveket böngésző kutató számára feltünően - az általa bevezetett modern stratégiai fogalmak szinte mindegyikét felfedezni véljük már Szun-ce (Sunzi) müvében, A hadviselés törvényeiben vagy más kínai gondolkodók, például Modi (i. e. 5. sz.) írásaiban is. Ilyen például az elrettentés, a korlátozott háború, a leszerelés, a tárgyalás, az alku, a fenyegetés, az ígéret, az elköteleződés, a hitelesség, a megtorlás, a hazardírozás, a meglepetés, a bizalom és a csalás.

Könyvének bevezetőjében Schelling például leszögezi: „Hasznos megkülönböztetést tehetünk az erő alkalmazása és az erővel való fenyegetés között. Az elrettentés a potenciális erö kihasználásával foglalkozik, vagyis azzal, hogy miképpen tudjuk meggyőzni a potenciális ellenséget arról, hogy a saját érdekében 
valamit ne tegyen meg. [...] Az elrettentés elmélete valójában azt vizsgálja, hogy hogyan tudjuk ügyesen elkerülni a katonai erő bevetését, és ehhez többre van szükség, mint katonai jártasságra.” (Schelling, 1980, 5.)

Vessük ezt össze az i. e. 6-5. század fordulóján élt Szun-ce szavaival: „Minden hadviselésnek törvénye, hogy legjobb épségben hagyni az ellenséges országot. [...] Nem is harcolni, mégis alávetni az ellenséges sereget, ez a legjobb." (Szunce, 1998, 25.)

Szun-ce eklektikus gondolkodó volt, aki az ,út és erény iskolája”, valamint a legizmus tanításait alkalmazta a hadviselés elméleti szabályszerüségeinek kidolgozása során, a történelmi példák általánosítása és a saját gyakorlati tapasztalatai alapján. Egy másik mester, Modi vagy Mozi viszont egy olyan rendszert dolgozott ki, amelyet az i. sz. második évszázad vége felé önálló filozófiai irányzatként tartott számon a kor nagy historikusa, Sze Tan (Sima Tan) (Sze-ma Csien [Sima Qian], a híres történész-krónikaíró apja). Fung Yu-lan A kínai filozófia rövid története címü müvében Modit és követőit, a „motistákat” a szétesőben lévő Csu(Zhou) korszak ,etikus vándor kardforgatóiként”, egyfajta - ha lehet így mondani - kínai szamurájközösségként jellemzi, akik „bármikor készen álltak a harcra” (Fung, 2003, 81.), de mindig csak erkölcsileg magasztos cél érdekében, a gyengébbek védelmében, az igaztalan támadások elhárításában.

A motizmus - fénykorában - a kínai szellemi életet domináló konfucianizmus legnagyobb bírálója és ellenfele volt, de a Han-korban feledésbe merült. Tökei Ferenc ókori kínai filozófiai müvekböl válogatott szöveggyüjteménye (1980) Mo mester tanításainak könyvéből „,csak” 14 fejezet fordítását közli, holott a teljes mü 71 fejezetből áll (igaz, ezekből 18 már végleg elveszettnek tủnik, noha a kínai régészet még mindig hajlamos a szenzációs meglepetésekre). Az Orientalisztikai Munkaközösség egyik füzetecskéje (Tőkei, 1998) ezt öt további fejezettel egészíti ki. A Mozi tehát egy olyan klasszikus kínai filozófiai alapmü, amelynek (ha jól tudom) még mindig nincs teljes és annotált magyar fordítása.

Modi elutasította a konfuciánusok családcentrikus önzését és a szertartásokhoz való ragaszkodásban megnyilvánuló álszentségét, szembeállítva ezeket az „egyetemes szeretet” elvével és a későbbi nyugati értelmezésekben „utilitáriusnak”, azaz „haszonelvünek” nevezett megközelítéssel, ami viszont a mai, korszerủ stratégiai játékelmélet felfogásával hozható párhuzamba. Ezt egy olyan „pragmatikus realizmust" tükröző gondolkodás-módszertani szisztéma egészítette ki, amely a valóság objektív megismerését helyezte középpontba tények, szakértői vélemények és megalapozott következtetések segítségével. Ez volt az egyetlen eredeti, Kínában született, valódi logikai rendszer, amelynek gondolati szigorúsága és könyörtelen objektivitása a később is zömében konfuciánus beállítottságú kínai társadalmi elit számára nyelvezetében szinte felfoghatatlanul száraz, „prózai", szellemiségében pedig ijesztő és elutasítandó maradt, nem is csoda, hogy feledésbe merült. Az olyan motista kategóriák, mint például a kirekesztés elutasí- 
tása, az önfejlesztés, a „realizmus” (sanbian), a meritokrácia, a támadó, agresszív viselkedés büntetése és ,a sors tagadása”, vagyis az egyén döntési szabadságán alapuló felelőssége és mások megfelelői mind-mind megtalálhatók a mai modern stratégiai tanulmányok, a játékelmélet és a politikatudomány fogalom-, illetve eszköztárában.

Ebből a szempontból rendkívül tanulságos a Mozi 50. fejezete, ami magyarul nyomtatásban még nem jelent meg. Ebben a tanítványok leírják, hogy Modi értesülései szerint Kung Su-pan (Gong Shuban), a messze földön híres ács (egyben „hadmérnök”) különleges ostromgépeket készített Csu (Chu) állam uralkodója számára, amivel a Szung (Song) fejedelemség megtámadására készültek. Mo mester azonnal Csúba sietett, és ott találkozott Kung Su-pannal, akit szembesített viselkedésének erkölcstelenségével, mégpedig úgy, hogy először - fizetség ellenében - a segítségét kérte egy haragosának a megöléséhez. Kung Su-pan azonban kijelentette: „Az én elveimmel összeegyeztethetetlen, hogy emberek meggyilkolásában vegyek részt." Mire Modi mélyen meghajolt, és kifejtette, hogy Szung állam megtámadása nem kevés ember halálát eredményezné, tehát szintén nem tekinthető magasztosnak. Kung elismerte, hogy igaza van, de a helyzeten már nem lehet változtatni, mert köti a Csu uralkodójának tett ígérete. Mo mester ekkor megkérte, hogy eszközöljön ki számára kihallgatást az uralkodónál.

Csu királyának Modi logikus (analógiás) érveléssel bebizonyította, hogy a gazdag állam részéről az, hogy megtámadja szegény és gyenge szomszédját, „kleptomániával” egyenértékü, és nemcsak erkölcstelen, hanem célszerütlen is, a veszteségek felülmúlnák az elérhető nyereséget. Az uralkodó sem tagadta, hogy Modinak igaza van, de ennek ellenére közölte: az ostromgépek már elkészültek, és a támadás elkerülhetetlen. Mo mester ekkor leoldotta vastag börövét, és egy várfalakkal körbevett térséget jelképező objektumot formált belőle, amit fegyvereket helyettesítő pálcikákkal védelmezett. Kung Su-pan kilenc különbözö ostromgépmakettel intézett színlelt támadást a vár ellen, és Mo mester „pálcikakatonái" mind a kilenc támadást visszaverték. Végül Kung Su-pan zavartan kijelentette: „Tudom, hogyan győzhetnélek le, de nem árulom el.” Mire Modi azt válaszolta: „Tudom, hogy mire gondolsz, de én sem árulom el.” Az uralkodó ekkor megkérdezte, hogy mit ért ez alatt. Modi közölte, hogy Kung mester valószínüleg arra gondol, hogy ha őt, Mo mestert most itt megölik, akkor Szung védtelen marad. Ez azonban hiú remény. Modi hátromszáz tanítványa már Szung várfalain örködik, olyan fegyverekkel, amelyek Kung Su-pan ostromgépeinek is ellenállnak. „Rendben van! - kiáltott fel a Csu uralkodó. - Akkor hát mégse támadjuk meg Szungot!"

Ez a kis történet arról tanúskodik, hogy a motista hadmúvészetben már jelentős szerep jutott az olyan gondolati konstrukcióknak, mint például a hírszerzés, a katonadiplomácia, az elrettentés, a kiképzés, a szövetségkötés, a katonai segítségnyújtás, a kétoldalú hadgyakorlat (hadijáték) és a modellezés (igaz, még nem 
számítógépes, csak fizikai modellek segítségével). Az 50. fejezet egyébként azzal zárul, hogy hazafelé menet Modi áthalad Szung állam területén. Zuhog az eső, és Mo mester egy fedett helyen meghúzná magát, de az átjáró kapujában álló ôr nem engedi be. Így tehát - vonja le a tanulságot a fejezet szerzöje (minden bizonnyal Modi egyik követője) - ,aki a szellemek előtt bizonyítja érdemeit, azt a sokaság nem ismeri el. Aki viszont nyilvánosan kérkedik, azt megbecsülik."

A fentiek alapján a Középső-hegyek farkasa a Han-korban és az utána született meseváltozatokban - a konfuciánusok szempontjából - lehetett volna akár Modi vagy az ő egyik-másik követöje is.

A Mozi 21. fejezetében a mester az Ég Fiát (a királyt) idézve így szól tanítványaihoz: „Ha akár jóról, akár nem jóról hallotok, mindig jelentsétek feljebbvalótoknak. Mindazt, amit feljebbvalóitok helyesnek tartanak, nektek is helyesnek kell tartanotok, s mindazt, amit helytelenítenek, nektek is helytelenítenetek kell. Ha feljebbvalótok hibát követ el, akkor a megfelelö módon tanácsot adhattok neki, $\mathrm{s}$ ha egy alárendeltetek jó tulajdonságokat mutat fel, akkor ajánljátok őt a társaitoknak." (Tőkei, 1980, 254.) Ezért tehát - jelenti ki Modi egy másik fejezetben - a (jó) kormányzás alapja a felettessel való azonosulás. Eszerint „az államon belül csakis egyféle nézet létezhet, amelyet magának a hatalomnak kell meghatároznia" (Fung, 2003, 92.).

Ehhez képest Tung-kuo tanár úr egyáltalán nem azonosul, sőt még csak nem is müködik együtt a katonákkal (akik a gonosz farkast üldözik), ami egyértelmüen arra utal, hogy a Han-dinasztiától a Ming-korszakig terjedő bő másfél évezredben Kínában még a hivatalnoki elit is mély bizalmatlansággal és ellenérzésekkel tekintett arra a katonai vezető rétegre, ami vele párhuzamosan és őt kiegészítve, sőt védelmezve, a hatalom másik pillérét alkotta - és ezért a vetélytársa volt, akárcsak az eunuchok, vagy mondjuk a pénzügyileg sikeres, de a politikai hatalomtól mindig is távol tartott (vagy önmaguktól távol maradt) vállalkozók, iparosok, kereskedők, bankárok.

Schelling a stratégia elméletét és annak gyakorlati alkalmazásait nem szúkítette le a katonai konfliktusokra. Ő közgazdász, politológus, külpolitikai elemző, nemzetbiztonsági szakértő, a nukleáris stratégia egyik kidolgozója, leszerelési tanácsadó is volt, mint ahogy Szun-ce és más kínai „hadtudósok” gondolatait sem csak egy alkalmazási területen lehet hasznosítani. Egy helyütt Schelling párhuzamot von Machiavelli és a régi kínai császárok között, és megállapítja, hogy még abban az esetben is, ha hiányzik a bizalom és a jóhiszeműség a szembenálló felek között, vannak olyan diplomáciai húzások, amelyek mindkét felet távol tarthatják az önpusztító ellenségeskedéstől. Ilyen például a kínai és az európai diplomáciatörténetből egyaránt ismert túszok cseréje (az állandó külképviseletek személyi állománya kezdetben a másik félnél „vendégeskedő” magas rangú túszokból állt), a borivás egy kupából (hiszen ha egy kupából ittak, akkor biztosak lehettek abban, hogy a bor nem mérgezett), a nyilvános találkozók (az árulás, a csapdába 
ejtés, az orgyilkosság megelőzésére) és az (elfogott) kémek kicserélése. Ez utóbbival demonstrálhatták, hogy nem rejtegetik szándékaikat és képességeiket egymás előtt, nem törnek titokban egymás vesztére (Schelling, 1980, 20.).

Szun-ce külön fejezetet szentel a „kémek alkalmazásának”, és leszögezi: „A bölcs fejedelem [...] mindent igyekszik előre tudni. Ezt az elöre tudást [...] mindig emberektől kell megszereznünk. Bölcsesség és ravaszság nélkül nem tudunk kémeket alkalmazni, emberség és igazságosság nélkül nem tudunk kémeket kiküldeni, finom érzék s éleslátás nélkül nem tudjuk megítélni a kémek igazmondását. A háborúban ez a legfontosabb.” (Szun-ce, 1998, 105-111.)

Jen Hszüe-tung (Yan Xuetong) (2015) ismerteti a Csin- (Qin) kor előtti kínai gondolkodók elméleteit a Tavaszok és őszök korának és a Hadakozó fejedelemségek korának viszonyaiba ágyazva, s a kínai filozófia történetéből hét klasszikus mester (köztük Konfuciusz, Szun-ce és Modi) müveit vizsgálja meg. Ezek alapján megállapítja, hogy az ősi kínai iskolák és a modern kínai hatalom felfogásában vannak közös elemek, amelyek közül kiemelhetjük az erkölcs és a nemzetközi rend szoros összefüggését. A klasszikus kínai hagyományokról tehát a mai Kína viselkedésének tanulmányozásakor sem szabad megfeledkezni.

\section{IRODALOM}

Fung, Y. (2003): A kinai filozófia rövid története. (ford. Antóni Cs.) Osiris: Budapest

Mozi. Chinese Text Project, http://ctext.org/mozi/gong-shu/ens

Rácz L. (2015): A kínai össznemzeti erő kutatásának helyzete Magyarországon. In: Salát G. (szerk.): Kínai álom - kínai valóság. Budapest: Typotex Kiadó, 126-145.

Rácz L. (2017): Világháború a Távol-Keleten (1894-?). In: Salát G. - Szilágyi Zs. (szerk.): Traumák és tanulságok - a II. világháború öröksége a Távol-Keleten. Budapest, Typotex, 10-27.

Schelling, T. (1980): The Strategy of Conflict. Cambridge: Harvard University Press

Szun-ce (1998): A hadviselés törvényei. (ford. Tökei F.) Budapest: Balassi Kiadó, http://mek.oszk. hu/01300/01345/01345.htm

Teller, E. (1987): The China Syndrome. In: Teller, E.: Better a Shield than a Sword. New York: The Free Press, MacMillan Inc.

Tian Y. T. (2007): The Wolf of Zhongshan and Ingrates: Problematic Literary Contexts in Sixteenth-Century China. Asia Major, 20, 1, 105-131. https://pdfs.semanticscholar.org/ c4a7/5099a850c79300f45c63e7c6bb9b99111417.pdf?_ga=2.263243210.774226780.15493630561848273354.1549363056

Tőkei F. (1980): Kinai filozófia. Ókor. Budapest: Akadémiai Kiadó

Tőkei F. (1998): Kinai szofisztika és logika. Budapest: Orientalisztikai Munkaközösség-Balassi Kiadó

Tsang, S. - Men, H. (eds.) (2016): China in the Xi Jinping Era. Nottingham: Palgrave-Macmillan

Yan X. (2015): Ancient Chinese Thought, Modern Chinese Power. Princeton: Princeton University Press 